THURSDAY, MAY 9, 1878

\section{PHYSICAL SCIENCE FOR ARTISTS}

\section{I.}

WE have it on the high authority of Lord Beaconsfield that the English School of Artists is arriving at a pitch of unexampled excellence, and that English art is in the future to be the cynosure of an admiring world.

It is Lord Beaconsfield's opinion that the time has arrived in which we may speak of a school which has flourished for a century with some accuracy of deduction as to its principal features. The principal features of the English school are, he thinks, now recognised. "All will admit that it is a school of great originality. All will admit that, in some provinces of painting, it has certainly established a reputation which may be rivalled by some nations, but which can be surpassed by none. Its power of portraiture is recognised in the most classic galleries. As far as landscape painting is concerned, it has achieved the highest aim of both branches of the art-whether ideal, like the enchanted castle of Claude Lorraine and the classic groves and solemn temples of Poussin, or whether it has competed with the freshness of Hobbema or Ruysdael, English art can match the chefs d'culvre of every country."

This is high praise, and we may gather from it that so far as the reproduction of form and colour goes our artists have arrived at the highest knowledge and skill. Of late years also, we are told, the English school has given an indication of aiming at a higher range of imaginative composition than has hitherto prevailed; and this Lord Beaconsfield holds is natural, because if there is an imaginative nation in the world it is the English nation. "It is the nation that has produced the greatest number of poets--the greatest number of illustrious poets -and, therefore, the British artist has a heritage of imagination which ought to be to him a fund of inspiration." Nor is this all. "He has also another advantage which no great school has yet possessed--he has a larger range of subjects. What the pictures of antiquity were we know very little. We know very well that Zeuxis painted a curtain that deceived his patron, but if that were a test of his school it might, I believe, be stood by the commonest scene-painter of the nearest theatre. With regard to the Italian masters, we know their admirable works abound; they established, not one school, like England, but many schools. Those schools produced many pupils, and their prolific works charmed and instructed the world. But if you look to the great creations of the Italian schools, you will find, generally speaking, as far as subjects are concerned, their range was extremely limiteci. They drew their inspiration from two religionsthe Christian and the Pagan; and every one must feel, when he examines a gallery of Italian art bow much it is to be regretted that such genius and power should not have commemorated the great acts of their own history. . . ."

Under these circumstances Lord Beaconsfield takes a very favourable view of the English school. He believes that "there is a feeling which will not be satisfied in the works of art if art does not aim at the production of the highest modern style of imaginative creation." That our artists

Vol. XVIII.-No. 445 will shine here the noble speaker is convinced, "I rely on the fact that there never has been a limit to the increasing excellence of English achievement when a fair and just opportunity was offered to it ; and, therefore, I do look forward to a period of which, I think, we have many symptoms and encouraging circumstances about us, when imaginative art will be characteristic of the English school, as well as that sense of humour and that exquisite feeling of nature and intellectual delineation of portraiture to which I have before referred."

The result predicted by Lord Beaconsfield is of course a consummation deroutly to be wished, and if it be true that Art is Nature passed through the alembic of Man, then this highest style of imaginative creation should largely increase the number of students of science in this country, because, although Lord Beaconsfield was careful not to say too much about Nature, she is there all the same, and the laws which underlie the phenomena which it is the function of art to embody should, at any rate, possess some interest to the artist, and if he is to surpass Nature, he must not hope to do this by evading her.

In art as in science, imagination must have a basis to work upon, and the surer the basis the more will the imaginative effort which transcends it be in sympathy with those hidden powers of the mind and those hidden feelings which it is the function of art to bring into play.

What little I know of the history and development of art would seem to show that in the early days at all events the artist was second to none in his appreciation of the science of the time. Geometry was rapidly applied to perspective, anatomy to form, and although the dwellers in Italy had the finest examples of ancient art to appeal to, it is not difficult to trace the rise of such men as Leonardo da Vinci and Michael Angelo to the direct influence of the study of anatomy first introduced at the University of Bologna. Da Vinci was, as is well known, almost as famous for his knowledge of science as for his productions in art. Indeed the anatomical studies carried on in the wonderful medical schools of Italy during the Middle Ages may be said to have left a greater mark on the world from an art point of view than they have done in the domain of the science of surgery.

Galileo, when he took so large a share in founding the physical science of to-day, was a student of medicine; the wonderfully regular swing of that famous lamp at Pisa suggested to him in the first instance a method of observing the flow of blood through the veins. The idea that here was a perfect method of dividing the flow of time-the idea of the pendulum clock-did not come till afterwards. Still the teaching of the medical school was no more to Galileo than it had previously been to Leonardo da Vinci or to Michael Angelo.

Now what is the condition of things to-day? We might be in the same position with regard to physical science-the science of colour-as Da Vinci and his contemporaries in the 15 th century were with regard to biological science--the science of form. The whole range of physical science-a branch of knowledge which has existed for two-and-a-half centuries, but which bas lately been developed enormously precisely in those directions of the greatest value to the artist, has not yet been annexed by the students of art.

So far as I can see there is not among artists gene- 
rally--among those even who acknowledge their obligations to mathematical and biological science in the regions to which I have referred-the notion that they have anything to learn from physical science-physical science being reduced, at all events it will be convenient that in what I now say I shall take it as reduced, in the main, to optics. There seems to be a sort of notion that there are no laws underlying the phenomena of air, and sky, and sea; that while the shape of a horse's leg is defined by law, the order of colours, for instance, in a rainbow, depends upon the play of blind chance. Indeed I have been informed-and I may tell the story here because it hammers my point home better than anything I could say-that an eminent artist, now living, who had painted a rainbow practically inside out, when the picture was returned to him in order that the colours might be corrected, was so indignant with this attempt to interfere with this special development of the "highest style of imaginative creation," to use Lord Beaconsfield's words, that he charged the tritle of $20 \%$. for attempting to place the colours in the order in which monotonous naturc perversely insists they shall stand.

This is a general attitude, not only of artists, but of wouldbe teachers of art, and these latter piteously make tempting officers of the whole range of theology for science to work her wicked will upon, if only art may be spared from her contaminating touch. This is not, however, the universal attitude, as I can abundantly testify. Some of our modern painters do most enthusiastically enter into the study of physical science not only for its own sake, but in order to embrace it in their art. It has been my great privilege during the last few years to discuss with painters of the highest eminence questions bearing on art which have arisen from my own investigations in another region of work, and in the study of which the works and observational powers of the artist have been of the greatest value to me.

It is as a result of these many conversations that I have determined to put on paper a sketch of some of the many points in which I think the interest of the operation of nature's laws is as great from an artistic as from a scientific point of view. I shall, I hope, be able to throw these notes into order, but I shall content myself at first with giving an idea of the result of such studies upon art criticism. Whole reaches of art will remain untouched by physics, and its influence will be chiefly felt by the landscape-painter. It is only those who are ignorant of the development of art who will look with suspicion upon the new tests of truth with which artists can supply themselveswith the new ways of tracing effects to causes. Art criticism must gain considerably, for in place of jargon we may in time find common sense, and when once this basis is secured then the more secure will be the "highest style of imaginative creation" resting upon it.

I shall best indicate what I believe will be the influence of the study of optics in the future on art, by stating, by way of introduction, in its most naked form the result of an appeal to the newest branch of knowledge as a test of the truth to nature of several of the pictures in this year's Academy.

The recent results obtained by the workers in spectrum analysis have added so much to our former knowledge of the actions which go on when light is given out, or re- flected, or absorbed, that almost all the optics the painter really requires conveniently lies round the most recent work in molecular physics, for the reason that it is the action of molecules which builds up the world with which the artist has to deal.

The instance I shall take in this paper is the following one. One of the smallest of the developments of the new branch of optics supplies us with facts which can be embodied in a simple working hypothesis. The approximate truth of this can be brought to the test by the various colours of the sky. When I say "working hypothesis," I use a term well known to men of science to indicate a train of thought to work upon and test. It is a first approximation to a general grouping of many facts, and it is perhaps as much generated by imagination as by work. It is not a hypothesis in the ordinary sense of the word, because it has not borne sufficient tests, and it especially is not a thing to be dogmatic about (and by this I do not mean to imply that there is anything whatever which ever should be) but still I think it will serve my turn.

Although I have never painted a picture, and am no art critic, yet I have criticised the pictures in this and former years with the most intense pleasure from the scientific point of view. This year I have limited myself to sky colour, and I have prepared two lists, one, including those pictures which $I$ think in harmony with nature, and the other those which represent phenomena which, however probable in any other planet, are, I think, physically impossible in this.

I have done more. I have tested the hypothesis by the pictures. I have gone over those in which I was chiefly interested from my narrow point of view with two artist friends of great distinction, and I have asked them whether the view at which I have arrived in each case was correct. The test I had applied had failed me in no instance.

Here then are the most salient examples included in my lists. I dealt with pictures, not artists, and carefully avoided seeking the artist's name in any case; but here I must bring them out, in order to refer to the pictures with sufficient completeness.

First, then, to deal with those pictures in which cloud and sky colour are, I think, correct :-

3. "The Timber Waggon"-C. E. Johnson. Accurate study of the absorption of light by a slightly hazy atmosphere.

63. "A Summer Flood"-H. R. Robertson. Colour of cumulus clouds glowing with the reflected light of sunset, perfect.

105. "The Cornish Lions"-John Brett. Remarkable picture: the colours and the atmospheric absorption, and therefore transformation of the colour, perfect.

153. "Evening"-R. C. Leslie. Wonderfully true rendering of a very rare effect.

230. "Estes Park, Colorado, U.S."-Albert Bierstadt. Very fine atmospheric study. The vapour rolling down the valley leaves its effect on the picture marvellously.

267. "Wandering Shadows"-P. Graham, A. Magnificent picture. Notice the effect of the atmo- 
sphere laden with aqueous vapour on the colour of the hill in the background.

268. "The Alps at Rosenlaui"--V. Cole, A. Gloriously true. The fading of colour in the distant bosses is perfectly rendered--the depth of the atmosphere can be gauged.

306. "Struyve Rocks, coast of Arran"-Geo. E. Hering. A red sunset, nearly perfect in colour from top to bottom; if the yellow had faded into green it would have been better. Compare red with 353 .

324. "Conway Marsh"-Jos. Knight. Sunset green, and deep blue hill admirable, but I doubt the colour of the foreground.

405. "Gleaners"-H. R. Robertson. Red, yellow, green, good. Moon nearly right, which is wonderful. (This by the way).

587. "Shining after Rain: Loch Etive"-Geo. E. Hering. The work of a careful observer.

615. "The Lowing Herd winds slowly o'er the Lea" -H. W. B. Davis, R.A. Perfect sunset (poor moon!). (Again by the way).

647. "An Autumn Walk"-A. E. Emslie. Good red and yellow.

739. "Sunset on the Jungfrau, Mönch, and Eiger"Jas. W. Smith. The blue below and red above on the snow perfectly rendered.

788. "The Written Valley, Wilderness of Sinai"Henry A. Harper. Good, but not so good as 739 .

I next come to those pictures which I think are inaccurate in colour.

86. "Christiana with her Family, accompanied by Mercy, arrive at the Slough of Despond: Mercy finds a way across"-R. Thorburn, A. Impossible cloud colours. Clouds bluer than sky and atmosphere nowhere.

146. "Solitude"-P. F. Poole, R.A. Impossible green sky and cloud.

20I. B. Riviere, A. Unnatural moonlight and impossible pea-soup shadows. The softness and colour of the latter suggest that $\mathrm{Mr}$. Riviere has never studied moonlight.

23r. "David, the Future King of Israel, while a Shepherd at Bethlehem "-J. R. Herbert, R.A. Colour impossible both in quantity and quality.

240. "A Dream of Ancient Egypt: the Morning of the Exodus"-Andrew MacCallum. I should like to hear the painter lecture on the connection of the colours of bodies with the light which falls upon them.

298. "Jarl Hacon in the Pentland Firth"-J. Hope M'Lachlan. High blotches of red over green and yellow impossible, and brick-dust beams of light proceeding from nothing still more impossible.

309. "The Sunrise Gun, Castle Cornet, Guernsey"Tristram Ellis. Sky colour good; impossible colour of water under sky conditions given.

353. "After the Rain"--W. H. W. Foster. Unnatural sunset, colour and distribution of light wrong.
424. "The Last Journey"-Clara Montalba. Impossible green sky; the sun is neither setting nor set.

483. "An Autumn Sunrise" - Cecil G. Lawson. Interesting as a foretaste of the future when the sun shall have cooled.

525. A. Dixon. Green hopelessly wrong.

542. "The Dee Sands"-J. W. Oakes;, A. Sky colours impossible with so bigh a sun.

555. "The Last of the Wreck"-E. Ellis. Green clouds!

630. "An Incident by the Wayside"-Mark Anthony. Impossible blue sky.

These, then, are the pictures I shall use as texts in my future notes. J. NORMAN LOCKYER

\section{THE AMERICAN STORM WARNINGS}

T HAVE now to direct attention to "Atlantic Storms,Whence they come and where they go?" All storms that cross the Atlantic Ocean to the coasts of Europe come from the equatorial zone of the Atlantic from the Pacific Ocean, or are developed from depressions on the American continent by peculiar operations of the law of atmospheric movements. The most prolific source of storms for the field of observation just sketched is the Pacific, but all the disturbances coming thence do not necessarily originate there. As I have stated, storms pass over the Pacific from the Asiatic as they do from the American continent over the Atlantic, but generally in more northerly latitudes. Their number cannot be accurately determined until a similar system of observation to that now in operation from the West Indies to Newfoundland is organised on the Eastern coast of Asia. As it is we are dependent on observations made along the Pacific coasts of the United States, British territory, Mexico, and the Central American States, for information regarding the arrival of storms from the westward on this continent. Fortunately the observers are now numerous enough to constitute an effective guard against the possibility of even a small storm centre passing inland unnoticed. These coast observations furnish reliable evidence of the fact that storms arrive on this continent from the Pacific much in the same manner as Atlantic storms reach Europe. It is my purpose to trace as closely as possible the movements of the various types of storms that originate in or cross the Atlantic from west to east, and I will begin with those whose first appearance is observed on the Pacific coast of the United States.

It has been noticed that storm areas approach these Pacific coasts as large depressions with a comparatively low energy of rotation around their centres. But when the area reaches the line of the coast or cascade range of mountains in Oregon and Washington territory, its outline is changed from the distorted circular to that of the irregular elliptical, and the northern end of the latter figure is carried toward the coast line more rapidly than the southern one, causing, as a rule, the first rainfall in the line of first contact with the land. Therefore, over Vancouver's Island and Western Oregon a rapid condensation of atmospheric moisture takes place which so : Continued from p. 7 . 